\section{Ciążąca (nie)obecność. Gombrowicz wobec wojny i Żydów}

\author{
Agnieszka Dauksza
}

TEKSTY DRUGIE 2016, NR 2, S. 211-230

DOI: $10.18318 /$ td.2016.2.11
Stypendystka wsparta finansowaniem Fundacji na rzecz Nauki Polskiej (FNP) Tekst powstał w ramach grantu finansowego ze środków Narodowego Centrum Nauki przyznanych na podstawie decyzji numer DEC-2013/11/N/ $\mathrm{HS} 2 / 03509$.

\section{O} bsesje, impotencja, perwersja, wojna, erotyka i żydowskość. Zestaw kategorii jawi się jako pokusa i zarazem zapowiedź spełnień współczesnego badacza/ współczesnej badaczki kultury. Także w niniejszym ujęciu, gdyż nieoczekiwanie satysfakcji ich rozpoznania dostarcza lektura pisarstwa Witolda Gombrowicza.

„Istnieje ktoś, kto się nazywa Witold Gombrowicz... podrzędny literat na emigracji w Argentynie, dekadent, destruktor i dezerter, gorszyciel i zdrajca" [WA 4741]

1 Kolejne cytaty z dzieł Gombrowicza lokalizowane są następująco: Pornografia, [P]; Kosmos, [K]; Bakakaj i inne opowiadania, [B]; Wspomnienia polskie. Wędrówki po Argentynie, [WP] i [WA]; Testament. Rozmowy z Dominique de Roux, [T]; Varia I. Czytelnicy i krytycy, [V]; Dramaty. Iwona, księżniczka Burgunda, [D]; Dziennik 1953-1969, [Dz]; Kronos, [KR]. Cytaty pochodzą z następujących wydań: Bakakaj i inne opowiadania, Wydawnictwo Literackie, Kraków 2002; Dziennik 1953-1969, Wydawnictwo Literackie, Kraków 2013; Dramaty, Wydawnictwo Literackie, Kraków 2015; Ferdydurke, Wydawnictwo Literackie, Kraków 2013; Kosmos, Wydawnictwo Literackie, Kraków 2014; Kronos, Wydawnictwo Literackie, Kraków 2013; Pornografia, Wydawnictwo Literackie, Kraków 2014; Testament. Rozmowy z Dominique de Roux, Wydawnictwo Literackie, Kraków 2012; Trans-Atlantyk, Wydawnictwo

\section{Agnieszka Dauksza}

- przygotowuje w Katedrze Antropologii

Literatury i Badań

Kulturowych WP

UJ pracę doktorską poświęconą afektom w literaturze i sztuce modernizmu. Autorka książki Kobiety na drodze.Doświadczenie przestrzeni publicznej w literaturze przełomu XIX iXX wieku (2013). Współautorka eseju filmowego Płaszów. Odkrywka (Kraków 2013) oraz projektu Krakowskie sny Amona Goetha (Kraków 2013). Kontakt: agnieszka.dauksza@ gmail.com 
- w ten oto sposób pisarz rozpoczyna swoje Wędrówki po Argentynie. Wyraźnie ironiczny stosunek do swojej kreacji jest odpowiedzią na wizerunek autora stworzony w realiach PRL-owskich. Zapewne ten żart nie jest jednak zupełnie bez pokrycia. Intrygują mnie zwłaszcza epitety „dezerter” i „zdrajca”, a to dlatego, że uchylenie się przez Gombrowicza od pogardzanych powinności patriotycznych powraca ciąłym echem w jego twórczości². A mówiąc ściślej: fakt ten powraca o tyle, o ile wiąże się z inną, stałą bohaterką dzieł tego autora - wojną. Choć zmieniają się motywacje, obiekty i konteksty, wojna nieodmiennie pozostaje w tle. Wyczuwalne jest to nie tylko we wprost nawiązującym do wojennej tematyki Ślubie, ale też w Trans-Atlantyku, w debiutanckich opowiadaniach odwołujących do wydarzeń i skutków I wojny, w Pornografii, Historii, Operetce, Dziennikach, Wspomnieniach polskich, Wędrówkach po Argentynie, Testamencie, Kronosie oraz - na innych zasadach - w Kosmosie, który jawi się z tej perspektywy jako obraz rzeczywistości „po” II wojnie. Zdaje się jednak, że dziełem najbardziej „nierozpoznanym” pod tym kątem wciąż pozostaje Pornografia, w której niczym w soczewce skupiają się interesujące mnie wątki.

„W ogóle Polski od 1939 r. nie oglądałem” - stwierdza Gombrowicz, lecz rozproszone w jego twórczości uwagi sugerują, że bardzo się tą Polską interesował, a czynione na samym sobie akty performatywne („zaklinam się i przysięgam, bo nie moja sprawa" [TA 180]) nie były w stanie wyplenić tego zaangażowania. Jedną z początkowych scen Trans-Atlantyku traktuję jako metaforę generalnej tendencji, mianowicie widocznej w tej literaturze obsesji na punkcie wojny i jej skutków: „bo Wojna. Ja powiadam: Wojna. On mówi: Wojna. Ja mówię: Wojna. On mnie na to: Wojna. To ja jemu: Wojna, wojna. Przestraszył się nie na żarty, aż mu jagody zbielały, łypnął na mnie okiem: A co? Maszże wiadomość jaką? Mówiono ci co? Nowiny jakie?" [TA 227].

Literackie, Kraków 2013; Wspomnienia polskie. Wędrówki po Argentynie, Wydawnictwo Literackie, Kraków 2013; Varia I. Czytelnicy i krytycy, Wydawnictwo Literackie, Kraków 2004.

2 Mam na myśli zarówno wyjazd Gombrowicza z Polski w 1939 roku, jak i jego odmowę wstąpienia do wojska w 1920 roku, o której pisał we Wspomnieniach polskich: „Ten rok 1920-ty uczynił ze mnie istotę nie taką jak wszyscy, wyodrębnioną, żyjącą na marginesie społeczeństwa. Takim życiem marginesowym żyję do dzisiaj [...]. Ten rozbrat z gromadą, z narodem, zmuszający do szukania własnych dróg i życia na własną rękę, począł się dla mnie w owym pamiętnym roku bitwy warszawskiej. [...] miałem uczucie, że jestem sam, sam, przeciwko wszystkim, że trzeba mi się zamknąć w sobie i nikomu nie dawać dostępu" [WP 313]. Por. także komentarze Janusza Margańskiego na ten temat - tegoż Geografia pragnień. Opowieść o Gombrowiczu, Wydawnictwo Literackie, Kraków 2005, s. 38-46. 
Mimo ostentacyjnie sygnalizowanej niechęci do martyrologii swego narodu pisarz notorycznie o wojnie dyskutował oraz korespondował. W początkowym, trudnym okresie pobytu w Argentynie pisał w Kronosie, że „ciśnienie wojny podtrzymuje mnie” [KR 83], a następnie dodawał w Testamencie: „Mnie podtrzymywała katastrofa. Katastrofa moja, Polski, Europy" [T 73]. Natomiast po wojnie, $W$ Wędrówkach po Argentynie, zwracał się do polskiego czytelnika następująco:

wbrew pozorom, wbrew temu iż moje pisanie nie dotyczy waszej rzeczywistości, pomimo że od czternastu lat żyję w warunkach odmiennych, jestem najściślej związany z waszymi przeżyciami. We mnie, jak w was, dokonało się załamanie dawnego ładu i wiem, jak wam wiadomo, że będziemy musieli stworzyć sobie nowy system pojęć i nowy porządek, zgodny z przemianami, jakie w naturze naszej nastąpiły [...] po tej łaźni, po tylu tak druzgocących doświadczeniach, po takiej katastrofie. [WA 4977]

Oczywiście wyraz uczuć bliskich empatii można postrzegać jako próbę „wkupienia" się w łaski odbiorcy. Nie zamierzam jednak dociekać czy rozstrzygać jakkolwiek pojętej autentyczności postaw pisarza. Chciałabym za to rozważyć literackie konsekwencje wyjazdu Gombrowicza z Europy w przededniu wojny w kontekście podejmowanych przez pisarza prób diagnozy (po)wojennego polskiego społeczeństwa. Zastanowię się - po pierwsze - nad ambiwalencją między niechęcią a wczuciem i ciekawością, oraz po drugie - nad napięciem między potrzebą zrozumienia swojego stanowiska a chęcią uświadomienia czytelnikom skomplikowania ich własnych postaw. Splot tych odczuć i motywacji jest - jak mam wrażenie - wyraźnie wyczuwalny w pisarstwie Gombrowicza, zwłaszcza w Pornografii.

\section{Porno-grafia}

Liczne sygnały wojny w tej powieści „rzuconej na krwawe tło Polski wojennej, przez Niemców zgwałconej” [T 120] są bezsprzeczne ${ }^{3}$. Witold „po latach świńskich, zduszonych, wycieńczonych, szarych lub wykrzywionych

3 Wagę problemu dostrzega Piotr Sadzik, określając wojnę "matrycą strukturyzującą" powieść Gombrowicza. Por. P. Sadzik Rzeczywistość straumatyzowana. Strach w Pornografii Witolda Gombrowicza, w: Kultura afektu. Humanistyka po zwrocie afektywnym, red. R. Nycz, A. Łebkowska, A. Dauksza, Wydawnictwo IBL PAN, Warszawa 2015. 
szaleńczo [...] w ciągu których tylko trupi odór" [P 38] przemieszcza się z „byłej Warszawy" [P 7] w okolice Bodzechowa, gdzie co prawda „są bandy po lasach” [P 13], więc dwory „zabarykadowane” [P 34], ale „póki co spokojnie”, „zacisznie - choć za ścianami, które nas chroniły, poczynał się ogród niewiadomych szelestów i powiewów, dalej zaś pola zdziczałe wojną" [P 34]. Co ciekawe, wyczuwalna jest jednak pewna sprzeczność, która przypomina, że deklaracja: „wówczas, a było to w 1943-im, przebywałem był w byłej Polsce i w byłej Warszawie, na samym dnie faktu dokonanego" [P 7], jest bez pokrycia i która jednocześnie dyskretnie zdradza faktyczną perspektywę piszącego. Gombrowicz, przygotowując powieść w 1956 roku, fantazjuje, że wojna ciągle trwa, choć jednocześnie ma świadomość jej skutków. Wyczuwalny jest również dystans czasowo-przestrzenny, np.: akcja rozgrywa się w 1943 roku, a Witold - na widok bielonego domu z facjatkami - reaguje nad wyraz sentymentalnie, jest „oszołomiony” na to „nieskalane zjawisko z dawnego, już tak odległego przedwojnia" [P 16]. Przemoc wojenna jest niby wydarzającą się tu i teraz wewnątrztekstową aktualnością: „wszystko tylko czeka, nasłuchuje [...], trzaśnie jak front się zbliży... Trzaśnie! To, panie, będzie rzeź, będzie wybuch, awantura [...], najgorzej, że nie ma dokąd wiać!" [P 15]. Lecz przecież w istocie właściwa katastrofa już nastąpiła: „wszystko było jak stężałe [...]. Sinawe i śpiące pola [...]. I niewiadome, i niezrozumiałe, ba, niepojęte, nie do ogarnięcia!" [P 10]. Bohaterowie czują się jak postaci z „umarłej fotografii” [P 19], ,jakby śmierć nasza, nachylona nad taflą wody, wywoływała w niej własne swoje oblicze" [P 19], krajobraz jest siny, jakby naznaczony śmiercią, pojawiają się częste, kumulujące się opisy ziemi, mogące sugerować, że nie jest to obszar „niewinny”, np. „gumno przed nami, czarna pochyła jego ziemia” [P 43], „czarno-brunatna ziemia gumienna rozkładała się aż po szopy” [P 43], „my podchodziliśmy. Po tej wzdętej, czarnej pochyłości” [P 43]. Wobec tych sygnałów zgoła inaczej brzmią diagnozy, że Pornografia to „podwójna zagadka ziemi i krwi"4.

Jednak jakie właściwie znaczenie dla tej powieści ma kontekst wojenny? Sądzę, że Gombrowicz realizuje scenariusz fantazmatyczny, podejmuje próbę wyobrażenia sobie sytuacji, gdy pozostałby w Polsce, a jednocześnie marzy o swojej sprawczości w realiach wojennych ${ }^{5}$. Otwierająca powieść deklaracja,

4 D. de Roux Gombrowicz - odprężenie inapięcia, w: W. Gombrowicz Testament. Rozmowy z Dominique de Roux, Wydawnictwo Literackie, Kraków 2012, s. 163.

5 Ciekawie w tym kontekście brzmią uwagi z Dziennika, gdy Gombrowicz - wspominając o powstawaniu Pornografii, tej „rzeczywistości naładowanej straszliwymi objawieniami", „porywa- 
że „Pornografia dzieje się w Polsce lat wojennych. Dlaczego? Trochę dlatego, że klimat wojny dla niej najwłaściwszy" [P 5], jest tyleż typowa ze względu na ostentację $\mathrm{i}$ „łatwość” zagrania Gombrowicza, co myląca. Wbrew pozorom realia wojenne nie są powieściowym sztafażem, ale właściwym „punktem zapalnym" opowieści, choć przyjdzie jeszcze rozważyć, dlaczego strategia pisarza jest „trochę na przekór" [P 5]. Tymczasem chciałabym zaryzykować tezę, że Pornografia, czy właściwie Porno-grafia od greckiej etymologii porne nierządnica i graphos - piszący, czyli pornographos, „piszący o nierządnicach” - jest zapisem fantazji autora. Fantazji o „Polsce przez Niemców zgwałconej" [T 120], o świadkowaniu temu aktowi, o obecności oraz o podejmowaniu aktywności w realiach wojennych, co przełamałaby jego dezercyjną „impotencję" i sprzyjałaby „odzyskaniu możności” [KR 54]. Wskazówkę do takiej interpretacji podsuwa sam Gombrowicz we wstępie do powieści:

Tej Polski wojennej nie znam. Nie byłem przy tym. W ogóle Polski od 1939 r. nie oglądałem. Opisałem to tak, jak sobie wyobrażam. To więc jest Polska imaginacyjna - i nie przejmujcie się, że czasem pomylone, czasem może fantastyczne, bo nie o to chodzi i to zupełnie bez znaczenia dla spraw tutaj się odbywających. [P 5$]$

Nie przypadkiem Gombrowicz wspomina o imaginacji, wyobrażeniu, fantastyczności. Jego narracja jest porno-grafią, czyli pisaniem obscenicznym, fantazjowaniem o Polsce wojennej, podglądaniem jej - w tym rozumieniu podglądactwa, które oznacza projektowanie tego, co chce się zobaczyć - myśleniem o nieładzie, rozprężeniu i anarchii, wreszcie - wyobrażaniem sobie siebie w tej rzeczywistości ${ }^{6}$. Oto źródła perwersyjności tej narracji.

Wyobrażeniowy charakter narracji Gombrowicza objawia się m.in. w specyficznej strategii opowiadania; wydaje się, że narrator, fantazjując, „odwiedza" w pamięci znajome miejsca i stopniowo „odtwarza" znany z przeszłości kontekst, wzbogacając go o elementy, które spodziewałby się zastać w wojennej Polsce: bandy, partyzanci, „zdziczałe pola” itd. W praktyce przypomina

jącej” i „podniecającej” - przyznaje się mimochodem, że zapoznanym właśnie nastolatkom "kłamie" i „opowiada o moich walkach w czasie ostatniej wojny..." [Dz 298-299].

6 Por. uwagi Andrzeja Kijowskiego, według którego Gombrowicz "na odległość wyczuł paradoksalne napięcie między dziwnością, potwornością okupacyjną a niezmiennym trwaniem dworu z jego rytuałem", A. Kijowski Dziennik 1955-1969, Wydawnictwo Literackie, Kraków 1998, s. $325-326$. 
to ciągłe poszukiwanie punktów odbicia. Metoda kojarzy mi się z echolokacyjnym sposobem orientowania się nietoperza w otoczeniu: emitowaniem sygnałów i oczekiwaniem na ich powrót, falę zwrotną pozwalającą określić położenie obiektów.

Opowieść Gombrowicza jest „ugodzona skosem” [P 38], co zapowiada pewną trudność orientacyjną, niemniej jednak do pewnego momentu wszyscy i wszystko - choć „inne zgoła" $i$ "podglądane jakby z kąta” - jest na swoim miejscu, jak dawniej, i pozwala uzyskać ów sygnał zwrotny: ludzie, miasta i wioski, elementy krajobrazu itd. Dopiero w wyobrażeniu wyprawy do Ostrowca fantazja Gombrowicza napotyka opór, gdy „jakaś nieobecność stawała się wyczuwalna, nie było mianowicie Żydów" [P 69].

Stosunek Gombrowicza do Żydów wydaje się jednoznaczny; autor po wielokroć stwierdza w swoich zapiskach, że „mnóstwo Żydów przyjaciół miałem i nigdy antysemityzmowi się nie oddawałem" [WP 2019], więcej - że nie jest "filosemitą sztywnym, wysilonym, ale filosemitą w stanie luźnym" [Dz 126]. Ze zgorszeniem mawia o czasie "nacjonalistycznych wybryków i antysemickich bójek" [WP 2638], cieszy się, że jakimś cudem jego „pochodzenie szlachecko-ziemiańskie” nie „zaszczepiło w nim antysemickiego kompleksu" [WP 2840]. Niejednokrotnie podkreśla wagę stosunków towarzyskich i przyjaźni z Żydami często zadzierzgniętych przy jednym stoliku w Ziemiańskiej, gdzie zresztą nazywano go podobno „żydowskim królem”, "gdyż wystarczało abym zasiadł przy stoliku, a już ściągały doń rzesze Semitów" [WP 2854]. Oprócz uznania dla inteligencji, przenikliwości, talentów, „niepokoju duchowego" i "krytycyzmu" zapoznanych Żydów docenia także ich wpływ na społeczeństwo: „Żydzi tak swoistą i wybitną mieli rolę w rozwoju polskim owych lat, że przemilczeć ich nie można". Jednak było coś jeszcze, co decydowało o tym upodobaniu: ,ja poniekąd miałem z nimi jedną rzecz wspólną, a mianowicie - stosunek do formy" [WP 2860].

Gombrowicz stwierdza, że tym, co go różniło od międzywojennego społeczeństwa, a zwłaszcza ludzi z jego środowiska, był fakt, że „ruszali się, mówili, myśleli, czuli w trybie raz na zawsze ustalonym, po przodkach odziedziczonym" [WP 2866], co zmieniło się dopiero "gdy wojna i rewolucja przełamały ten rytuał i jęły ugniatać ludzi jak lalki woskowe”. Co innego Żydzi, których forma przez „wieki wygnania i ucisku” „ulegała wielu wypaczeniom” i którzy:

często samych siebie odczuwają jako karykaturę, [...] a ich napięty stosunek do formy, że ona tak ich dręczy, albo śmieszy, albo poniża, to że Żyd nigdy nie jest sobą w stu procentach, jak będzie sobą chłop, czy szlachcic, 
o formie po pokoleniach odziedziczonej, z którą się zrósł doskonale, to że Żyd zawsze musi być jakąś kompromitacją formy i jej katastrofą - to wszystko mnie w nich urzekało. Gdyż do tego ja dążyłem w mojej sztuce - do uwydatnienia zmagań człowieka z formą. [WP 2889]

Owo rozchwianie w formie jest dla Gombrowicza ogromnym, subwersywnym potencjałem. W jego logice charakterystyczne dla Żydów doprowadzanie do skrajności i maksymalnego napięcia pozwala obnażać sztuczność wszelkich form7. We Wspomnieniach polskich autor opisuje scenę z przedwojennego Zakopanego, gdy pod hotelem Bristol ustawiła się „starsza już Semitka", ciotka jednej z jego koleżanek, Krysi Skarbek, i zaczęła po imieniu wołać dziewczynę, na co obecne towarzystwo „struchlało”, nie wiedząc, jak ukryć zmieszanie. Niewerbalizowana dotąd wiedza o żydowskim pochodzeniu dziewczyny musiała stać się teraz faktem towarzyskim: „Nie było w tym pogardy, ani nienawiści - była tylko okropna niezaradność, nieumiejętność przekroczenia konwenansu”; „trzeba było widzieć to grono ludzi, przecież obytych w świecie: oczy znieruchomiałe, wbite w ziemię, twarze natężone [...], udawali, że o niczym nie wiedzą" [WP 289o]. Ocena Gombrowicza jest wówczas dość nieoczekiwana - „świat żydowski wszczepiony w świat polski ma niezwykle rozsadzające znaczenie", gdyż ukazuje jego nieautentyczność i jest to „jedna z największych szans na wypracowanie formy nowoczesnej [...] zdolnej sprostać teraźniejszości" [WP 289o]. Dlaczego jednak - skrótowo i upraszczająco - próbuję teraz rekonstruować poglądy Gombrowicza? I jakie ma to znaczenie dla proponowanego przeze mnie zarysu analizy Pornografi?

Podążanie tym tropem doprowadza bowiem do najbardziej niepokojącego i „ciemnego" konglomeratu wątków w Pornografii. Mówiąc wprost: nie sądzę, by Żydom - jak zwykło się uważać - poświęcone było jedynie owo jedno pamiętne zdanie - obserwacja zmian w Ostrowcu. W tej intuicji utwierdza mnie ponowna lektura opisu podróży do tego miasteczka:

Rozejrzałem się po okolicy. Stąd, z wyżyny, widać już było Kamienną i nawet dochodził ledwie dosłyszalny łoskot pociągu, który zbliżał się do Bodzechowa. [...] jak okiem sięgnąć, senna odwieczność, ale zakneblowana,

7 Por. interesujące rozważania Włodzimierza Boleckiego na temat "zniewolenia” formą - W. Bolecki Dodatek krytyczny, w: W. Gombrowicz Ferdydurke. Pisma zebrane, Wydawnictwo Literackie, Kraków 2006; tegoż Antynowoczesna nowoczesność (Ferdydurke Witolda Gombrowicza, 1937/1938), w: Modalności modernizmu. Studia, analizy, interpretacje, Wydawnictwo IBL PAN, Warszawa 2012, s. 434-438. 
zduszona, wzięta za pysk. Dziwny odór bezprawia przenikał wszystko. [...] mijaliśmy ich, tych ludzi pojawiających się, szli po ścieżce, ten w kaszkiecie, ów w kapeluszu, a dalej spotkaliśmy wóz z tobołami, z całym czyimś dobytkiem, posuwał się krok za krokiem [...], jakaś kobieta zatrzymała nas [...], ujrzałem twarz dość subtelną w chustce, jaką noszą baby [...] a dekolt miała głęboki, balowy czy też wieczorowy, elegancki [...], coś chciała powiedzieć, ale zacięła usta, znów miała mówić, ale machnęła ręką, odskoczyła - i stała na szosie, gdy oddalaliśmy się. Karol się roześmiał [...] Przejechaliśmy obok posterunków niemieckich przed fabryką, miasteczko było to samo, co dawniej, zupełnie to samo, te spiętrzenia i rury wielkich pieców fabryki, jej mur, dalej most na Kamiennej i szyny kolejowe i główna ulica, wiodąca do rynku [...]. Tyle tylko, iż jakaś nieobecność stawała się wyczuwalna, nie było mianowicie Żydów. [P 69]

Zwykle w Pornografii „badanie” rozmiarów katastrofy oraz konfrontowanie się z kolejnymi postaciami i przedmiotami umożliwia Gombrowiczowi budowanie (mikro)relacji, określanie się „wobec” oraz bycie „pomiędzy”. W Ostrowcu coś się zmienia, jakby Witold „wylądował na jakiejś innej planecie” [P 12], bowiem „wyczuwalna jest nieobecność, a wysyłany sygnał pozostaje bez odzewu. W miejscu Żydów jest „puste znaczące”, zbudowanie relacji staje się niemożliwe. To jedno zdanie nie pozostaje jednak bez konsekwencji. Niepokojące są wzmianki o zakneblowaniu i zduszeniu poprzedzające spostrzeżenie o nieobecności Żydów, ale też zastanawiające okazują się fragmenty kolejne:

Jednakże sporo ludzi na ulicach, ruch nawet, miejscami ożywiony, tam baba śmiecie wyrzuca z sieni, tu ktoś idzie z grubym sznurem pod pachą, przed sklepem spożywczym gromadka, a chłopczyk kamieniem usiłuje trafić we wróbla, który przysiadł na kominie [...]. Jak najprędzej opuściliśmy ten dziwny Ostrowiec i odetchnęliśmy, gdy bryczkę przyjęła znów na swoje miękkie łono ziemia zwykłej drogi polnej. [P 69]

Badaczce literatury Zagłady trudno pominąć takie skomasowanie charakterystycznych figur: pociągi i ich dobiegający z dala łoskot, szyny kolejowe, ludzie z tobołami, mury, niemieckie posterunki, rury wielkich pieców fabryki, wzmożony ruch, komin, niemożność ekspresji, ożywienie tych, którzy pozostali, porządki, rzucanie kamieniem. A pośród tego nieobecność Żydów. 


\section{Życio-śmierć}

Czy należy postrzegać tę nieobecność w kategoriach braku lub pustki? Niekoniecznie, wszakże istotna jest jej oddziałująca właściwość - pewna „wyczuwalność", którą można rozumieć w duchu derridiańskim jako obecność śladu . Bohater Gombrowicza mówi o odczuwaniu nieobecnych Żydów, sam Gombrowicz wielokrotnie przekonuje, jak wiele zawdzięcza wpływowi żydowskich intelektualistów, przyjaciół i nieznajomych, którzy kształtowali jego światopogląd, stanowili punkt odniesienia, byli towarzystwem w niedoli samotności i społecznego nieprzystosowania. Nie przypadkiem autor stwierdza, że „bezmiary zbrodni, dokonanej na Żydach, i mnie przeszyły na wskroś i na zawsze" [Dz 126]. Nie są to czcze słowa, a przejawy żalu, tęsknoty i wdzięczności powracają w całej jego twórczości. Podobne gesty pisarza mają podwójny wymiar - są zapewne konsekwencją wciąż odczuwanego przez niego wpływu, mentalnej, pamięciowej bliskości, która przezwycięża fizyczną nieobecność Żydów. Jednocześnie dzięki nim dochodzi do „wywoływania” żydowskich widm, tekstowego aktualizowania ich obecności. Korzystając z języka Derridy, działania Gombrowicza można określić jako melancholijne przywoływanie obecności tych, którzy odeszli, „kontrsygnaturowe” pozostawanie z nimi w relacji, gościnne zapraszanie ich do swego tekstu, wychodzenie im naprzeciw, dążenie do spotkania⿳9. Przestrzeń tego spotkania, literatura, okazuje się łączem między nieobecnością i obecnością, śmiercią i życiem. Pisanie Gombrowicza wywołuje ruch, który pozwala przekroczyć dychotomię bytu i niebytu, a który przez Derridę określany jest jako la vie la mort - „życio-śmierć”. Dochodzi tym samym do odrzucenia łatwych podziałów między dwoma porządkami, (nie)obecność nie jest zaprzeczeniem czy brakiem obecności, jest natomiast śmiercią bez negacji, czyli wciąż pewną formą życia. Ruch między śmiercią i życiem zagarnia wszystkich: zmarli są

8 Nie sposób w tym miejscu rozwinąć wątku śladowości. Zrobił to jednak przenikliwie Andrzej Zawadzki w książce Obraz i ślad, Wydawnictwo UJ, Kraków 2014.

9 J. Derrida Freud i scena pisma, w: tegoż Pismo i różnica, przeł. K. Kłosiński, KR, Warszawa 2004; tegoż To Speculate - on "Freud", w: The Post Card. From Socrates to Freud and Beyond, trans. A. Bass, University of Chicago Press, Chicago 1987. Piszą na ten temat m.in.: J. Momro Widmontologie nowoczesności. Genezy, Wydawnictwo IBL PAN, Warszawa 2014; A. Marzec Widmontologia. Teoria filozoficzna i praktyka artystyczna ponowoczesności, Fundacja Bęc Zmiana, Warszawa 2015; tegoż Widma, zjawy i nawiedzone teksty - hauntologia Jacques'a Derridy, czyli o pośmiertnym życiu literatury, w: Wymiary powrotu w literaturze, red. M. Garbacik, P. Kawulok, A. Nowakowski, N. Palich, T. Surdykowski, Libron, Kraków 2012; S. Karolak Widma (z) Zagłady, "Czas Kultury" 2013 nr 2. 
obecni w żywych, a zarazem żywi - nosiciele pamięci i tropiciele śladów zostają naznaczeni śmiercią, podobnie zresztą jak ich rzeczywistość kierowana życiodajną/śmiercionośną dynamiką.

Gombrowicz nie tylko mówi, że (nie)obecność Żydów można odczuć, ale również przez swoje teksty czyni ją odczuwalną. Strategia ta w pewien sposób wiąże się z przedwojennym postrzeganiem żydowskości jako swoistego farmakonu dla polskiego społeczeństwa "zasklepionego" w przeżytej i nieautentycznej formie. Wobec (nie)obecności Żydów i zaprzepaszczenia tego potencjału pisarz realizuje nieco odmienny scenariusz, mianowicie pragnie doprowadzić do spotkania osłabionej i „złamanej” polskości z widmową żydowskością. W uzasadnieniu tej śmiałej hipotezy pomocne będzie - choćby szczątkowe - zrekonstruowanie diagnozy Gombrowicza.

W zapisach z Dziennika z 1956 roku pisarz podejmuje się próby, by „tak z boku, na niewidziane, na oślep prawie” „zajrzeć do głów” Polakom i „zrobić im bilans dziesięciolecia" [Dz 324]. Prowokują go sygnały, które odczytuje z polskiej prasy; zastanawia się, ,czy możliwe jest takie zduszenie słowa, że ono niczym się nie zdradzi”. Postanawia wsłuchać się „nie w ich słowa; a w ich głos" i stwierdza:

Przeszli przez dwa olbrzymie doświadczenia: wojnę i rewolucję. I powiedzmy, że o tyle tylko mogą oni dzisiaj być kimś, coś przedstawiać, coś tworzyć, o ile te doświadczenia weszły im w krew. Albowiem przestali być ludźmi z roku 1938 - są modelami 1956. Jeśli utraciwszy tamtą rzeczywistość, nie przyswoili sobie dostatecznie nowej, jeżeli nie są, dość intensywnie, ani tym, ani tamtym, to czymże są? Niczym. Mnie właśnie zdaje się, że oni swego życia nie przeżyli. [...] Ich nieprzeżycie wojny. Polak bynajmniej wojny nie doświadczył. Doświadczył jedynie tego, że wojny nie da się doświadczyć - mówię, doświadczyć w pełni, wyczerpać - i tego że wraz z pokojem wraca natychmiast inny wymiar, ten normalny. Tak postawione zagadnienie miałoby przynajmniej tę zaletę, że nie ubezwładniłoby ich na czas pokoju pod względem myślowym, moralnym, uczuciowym - znając pojemność swojej natury ci ludzie łatwiej odnaleźliby równowagę. [...] Ich nieprzeżycie rewolucji. - A zatem cóż przedostało się z wojny do ich świadomości - co zostało sformułowane? Jakaś luźna myśl o „okropności” i nieco kulawego, moralizatorskiego patosu. W rzeczywistości ukończenie wojny zastało ich przewróconymi, ogłupiałymi, wypróżnionymi [...]. I na tę pustkę w nich spadł marksizm. Marksizm, wyobrażam sobie, spadł na nich zanim zdołali całkowicie 
przyjść do siebie, to jest do siebie z czasów przedwojennych. Toteż myślę, że oni nie przeżyli rewolucji, ponieważ nie mieli czym jej przeżywać. [Dz 325-327]

Gombrowicz wyróżnia zatem kilka poziomów tego „niedoistnienia w nowej rzeczywistości” - po pierwsze - nieprzeżycie, czyli nieprzepracowanie, niezwerbalizowanie, niewłączenie do narracji wydarzeń wojennych, których wspomnienie jest dla Polaków wciąż nierozbrojonym pociskiem tkwiącym w samym centrum społecznego imaginarium. Gdy Gombrowicz mówi, że Polacy nie odczuli wojny, to zdaje się zakładać, że to, co cieleśnie, fizycznie doświadczone, nie zostało opracowane na poziomie mentalnym. Traumatyzujące afekty nie zostały odczute, uwięzione w ciałach nie miały szansy „wybrzmieć", nie były poddane racjonalizacji, nie weszły na poziom uczucia i emocji. Procesy żałoby i dystansowania się od bolesnych doświadczeń nie były możliwe, tym bardziej że na te znękane psychociała błyskawicznie została nałożona „klatka” komunizmu, , jak się nakłada klatkę na odurzone ptaki, jak się nakłada ubranie na człowieka nagiego" [Dz 327]. Wspólnota w stanie choroby została więc zakleszczona w kolejnej formie, marksizm był w tych realiach "systemem społecznym, w którym się żyje, którego się nie przeżywa" [Dz 328]. Według Gombrowicza polskie społeczeństwo żyje więc życiem upiornym - ludzie są "puści”, są „nikim”, przypominają fantomy próbujące machinalnie realizować zapamiętane sprzed wojny scenariusze zachowań, które są jednak rewidowane przez zasady dyktowane przez nowy system.

Zgodnie z tą logiką Polacy żyją , ,jakąś słabowitą, wstępną egzystencją", przede wszystkim dlatego, że wskutek nieprzeżycia wojny i rewolucji, „stracili wrażliwość" [Dz 329]. Symptomy są dla pisarza ewidentne: jego rodacy nie mają świadomości swego położenia, nie odczuli nawet zmian układu sił klasowych, gdy „proletariusz naraz wylazł na scenę i w czołowej roli” [Dz 326]. „Przespanie” rewolucji chłopskiej Gombrowicz przypisuje zresztą obu stronom: „inteligentom”, którzy powinni „choćby ze strachu silniej odczuć tę [chłopską - przyp. A.D.] obecność” [Dz 328] oraz samym chłopom: „twierdzę, że nawet po cichu i po kryjomu nie nawiedzają ich takie myśli" [Dz 329].

Równie ważnym objawem nie-życia Polaków jest według Gombrowicza ich niemoc twórcza. Zarzuca powstającej po wojnie literaturze jałowość, a oceniając pisarzy, twierdzi, że „Proust więcej znalazł w swoim ciasteczku, w swojej służącej i w swoich hrabiach, niż oni w dymiących przez lata całe krematoriach” [Dz 325-326]. Zastrzega jednak, że wcale nie uważa, „żeby ich 
impotencja artystyczna wobec wojny była wstydem, lecz przeciwnie, to było do przewidzenia":

Dlaczego tak się dzieje, że żołnierz idzie na front, doznaje okropności, sam nią się staje, a potem wraca do życia cywilnego jak gdyby nigdy nic... taki właśnie, jakim był przed wyruszeniem? Zdarzają się dawki za silne. Tych organizm nie przyjmuje. [...] jeśli Proust z hrabiów wydobył więcej, to dlatego że wśród hrabiów mógł poruszać się i czuć swobodnie, a i ciasteczko go nie przerastało - ale te cztery miliony zamordowanych Żydów to Himalaje! Zakazałbym tej typowo polskiej naiwności, która mniema, że tylko na szczytach jest coś do odkrycia. Na szczytach nie ma nic, śnieg, lód i skała - natomiast wiele jest do zobaczenia we własnym ogródku. [Dz 326]

Paraliż i niemoc odniesienia się do skali tragedii - według Gombrowicza naturalne i zrozumiałe - są pochodnymi błędnego założenia, że podły jest ten, kto z „wielkiego przeżycia” nie wyciagnnie „wielkiego wzruszenia i wiellkiej nauki" [Dz 327]. Co więcej, zdaje się, że impas polskich artystów, a zapewne także całej wspólnoty, wynika z niemożności zbudowania nowych struktur odczuwania. Raymond Williams słusznie przekonywał, że „pomiędzy przyjętymi interpretacjami a praktycznym doświadczeniem występuje często napięcie”, które niekiedy „wyraża się w formie zakłopotania, stresu, wzburzenia czy ukrywania czegoś"10. Owo napięcie jest oczywiście konsekwencją nieprzystawalności zastanych form do charakteru doświadczeń, chaosu i skomplikowania odczuwanej rzeczywistości, „zużycia się” starych struktur odczuwania i trudności zastąpienia ich nowymi, bardziej adekwatnymi.

Jednak - jak zostało już wspomniane - Gombrowicz nie tylko krytykuje i diagnozuje, ale też oferuje pewne scenariusze zaradcze. Na czym miałyby one polegać? Współczesnego czytelnika może z pewnością zdumiewać nieodmienna aktualność ocen pisarza. Mówiąc wprost, Gombrowicz niemal o sześćdziesiąt lat antycypuje wiele spostrzeżeń i tez Andrzeja Ledera z Prześnionej rewolucji...". Przenikliwość intuicji Gombrowicza nie wynika jednak ze znanego powszechnie polskiego pionierstwa cywilizacyjnego. Faktycznie, interesuje się on podobnymi kwestiami, patrzy na sprawę polską właśnie

R. Williams Marksizm i literatura, przeł. A. Chojnacki, E. Kasperski, PWN, Warszawa 1989, s. 215. 
dlatego, że jest Polakiem² ${ }^{12}$, lecz widzi ją z tej perspektywy zapewne dzięki temu, co nie jest w nim polskie. Z pewnością cenne okazuje się także psychiczne i fizyczne zdystansowanie, wszakże - jak wiadomo - z daleka widać więcej. Tym bardziej frapująca zdaje się rada pisarza, by wobec karkołomności odczucia i zrozumienia „szczytowej” tragedii Żydów zajrzeć do „własnego ogródka". Nieoczekiwanie staje się jasne, że na tym także polega strategia samego Gombrowicza, który - dzięki pisaniu Pornografii i sprawczości aktu literackiego - przenosi się wyobraźnią do wojennej Polski, w rodzinne strony ziem świętokrzyskich. Więcej, zmusza do tego również swego odbiorcę.

Już na wstępie omawianej powieści dość wyraziście zostaje zwerbalizowany podstawowy cel działań Witolda i Fryderyka: „przebić się przez kryształ tej sielanki" [P 20]. Dzieje się tak, gdyż zachowania i reakcje rodziny Hipolita wydają się nowo przybyłym zgoła niewspółmierne do realiów. Gombrowicz - przez powieściowe intrygi i subwersywne działania bohaterów - kolejno, zmaga się za pomocą „oddolnej” metody z wyszydzaną przez niego ideą ziemiaństwa: upokarza tradycyjną rodzinę, by w finale mieć do czynienia z domem pełnym trupów i panną (znowu) na wydaniu; „zarzyna” mszę w grocholickim kościele; przez komitywę Fryderyka i Witolda z młodymi, w kontrze do Wacława, poniewiera instytucję małżeństwa; wreszcie - za pomocą wątku „popsutego nerwowo” Siemiana - ośmiesza działalność partyzancko-wojskową.

Co ważne, Gombrowicz ma świadomość, że przypieczętowując upadek „odwiecznych" wartości, jednocześnie wystawia beznadziejną prognozę rzeczywistości powojennej, niemniej - jak utrzymuje - „lepsza jest nawet myśl raniąca, burząca, ale szczera i możliwie najgłębsza, naprawdę coś poruszająca, niż lękliwe utwierdzanie się w tradycyjnym uczuciu” [WA 4818]. W tym ujęciu jednostka nie znajduje już oparcia w kulturowych, sakralnych i społecznych protezach sensu. Dlatego pisarz przechodzi do realizowania "pozytywnej”, lecz niekoniecznie optymistycznej działalności „sensotwórczej”. O ile w innych utworach Gombrowicza tym pierwszym obiektem na drodze budowania nowej logiki bywały wróbel i strzałka (Kosmos) lub gotowa do obgryzienia kość (Dziewictwo), o tyle teraz ważna jest para młodych. Dlaczego oni? Gombrowicz podpowiada, że nie chodzi o indywidualne przymioty, inteligencję,

Ciekawie rozpatruje problem „polskości” Gombrowicza Zdzisław Łapiński, który dynamikę napięć między mentalnym poczuciem "bycia” i „niebycia” Polakiem postrzega przez pryzmat "fazowości ludzkiej biografii”. W konsekwencji wielu wypadkowych, „chcąc nie chcąc, godzi się Gombrowicz być Polakiem" - Z. Łapiński Ja, Ferdydurke, Wydawnictwo Literackie, Kraków 1997, s. 118. 
urodę, wdzięk czy w gruncie rzeczy nawet możliwość ich seksualnego połączenia - istotna jest młodość. Ale dlaczego właśnie młodość? Wielokrotnie komentowano ten wątek, czynił to zresztą także sam Gombrowicz. Z perspektywy tej analizy najistotniejsza wydaje mi się kwestia „niskości” i jakiejś pierwotności, potencjalności Karola i Heni, tego, że mogą być jeszcze „wszystkim”. Słowem, chodzi o ich „nieuformowanie”, które - pozyskane dla celów „żerującej na nich pornografii” - może z kolei stać się czynnikiem destabilizującym.

Akcentuję ten problem, gdyż mam poczucie, że na poziomie fabularnym najważniejszą intrygą jest „przejęcie” dla swoich potrzeb dwojga młodych bohaterów, potraktowanie ich „jak owych figurek z gutaperki dających się ugniatać na wszystkie sposoby, z których można zrobić wszelką potworność" i „wydać wszelkiemu najdziwniejszemu kształtowi” [T 18]. Faktycznie, młodzi nie są istotni jako indywidualności, praktycznie bez znaczenia jest również ich seksualność oraz to, co mogliby ze sobą robić (choć nie do przecenienia jest samo napięcie erotyczne, o czym szerzej za chwilę). Ważne jest jednak, co można „nimi” lub dzięki nim robić.

Kluczowa jest dla mnie scena, w której dochodzi do rozdeptania glisty. Nie przypadkiem następuje ona natychmiast po powrocie Witolda z Ostrowca, gdzie odczuł on dziwną nieobecność Żydów. Narosłe w opisie tej podróży napięcie wynikające z nagromadzenia zagładowych skojarzeń „rozlewa się” na kolejne zdarzenia. Witold - w drodze powrotnej z Ostrowca - wykazuje potrzebę konfrontacji z Fryderykiem, „męczy” go pytanie, co teraz robi jego towarzysz, choć wie też, że na pewno robi to z „zachowaniem wszystkich ostrożności” [P 69]. Tymczasem ucieczce Witolda z „tego dziwnego Ostrowca” odpowiada chęć Fryderyka, by uciec z tych okolic, z domu Hipolita: „czyby nie wracać do Warszawy [...] może lepiej jednak spakować manatki... Torował w sobie drogę tej decyzji, czynił ją nieznacznie coraz intensywniejszą, przyzwyczajał się do niej... mnie, siebie, okoliczne drzewa. Jak uważam? Bo, z drugiej strony, na wsi mimo wszystko lepiej..." [P 70]. Fryderyk - zawsze poruszony, zwykle „piwniczny”, w wojennej Warszawie handlujący „skórkami zajęczymi” [P 8], „w średnim wieku, czarniawy i suchy, z nosem orlim" [P 7] - w tym momencie jest przejęty do tego stopnia, że „wszystkie zmarszczki rozsiadły się i żerowały na nim, jak na trupie" [P 71]. Bezpośrednim następstwem rozmowy Witolda z Fryderykiem, której towarzyszy w tle „zalatujący z krzaków zapach kantarydy” (czyli trucizny produkowanej przez chrząszcze), jest właśnie scena, w której Karol wraz z Henią rozdeptują glistę: 
nie byłoby w tym nic ważnego, gdyby nie wzrok Fryderyka, który musiał patrzeć [...], przyssał się do tej glisty, szklany, wydobywając do dna jej męczarnię [...], Fryderyk zdrętwiały, niemy, ujęty w kleszcze bólu - nie mógł się ruszyć. [...] wszak ból, męczarnia są równie okropne w ciele robaka, co w ciele olbrzyma, ból jest „jeden”, podobnie jak przestrzeń jest jedna, nie dzieli się na części. [P 74]

Nie sposób nie dostrzec korespondowania dwóch obrazów: dziecięcego, niemal „niewinnego”, bezmyślnego okrucieństwa chłopca, który w Ostrowcu celował kamieniem we wróbla, i pary młodych „dla równowagi” wspólnie przydeptujących glistę. Wydaje się, że bohater Gombrowicza - komentując zabicie dżdżownicy - wciąż jeszcze myślami jest w Ostrowcu. Mówiąc o męczarniach glisty, poniewczasie mówi także - a może przede wszystkim - o cierpieniu ofiar wojny.

Łączy się tu kilka interesujących wątków. Po pierwsze, niższość, pierwotność, instynktowość młodych leży u podstaw Gombrowiczowskiego projektu „nowego odczuwania”. Pisarz zakłada bowiem, że młodość „w przyszłości głębiej, straszniej będzie się nam wdzierać w odczuwanie” [T 56]. Stanowi to nie lada obietnicę, gdyż jeszcze przed wojną Gombrowicz - obawiając się skutków katastrofy o trudnych do wyobrażenia rozmiarach - jednocześnie fascynował się tym, co nadchodzi:

Wojna? Zagłada Polski? Los bliskich, rodziny? Moje własne losy? [...] gwałt wyzwala to coś nienazwanego i nieuformowanego, czego obecność nie była mi obca, żywioł, o którym tyle tylko wiedziałem, że jest "niższy”, „młodszy” - i ruszający teraz jak powódź w czarnej i gwałtownej nocy. [...] od pierwszej chwili zakochałem się w tej katastrofie, której nienawidziłem, która przecież i mnie rujnowała, że moja natura kazała mi ją powitać jako okazję do połączenia się z niższością w ciemności. [Dz 204-205]

Oceniając polskie społeczeństwo powojenne, pisarz konstatuje, że wbrew jego nadziejom nie doszło do faktycznej erupcji nowych sił ciemnej witalności. Przeciwnie - po wojnie umocniły się i spotworniały wcześniejsze skłonności tego „narodu bez filozofii, bez świadomej historii, intelektualnie miękkiego, duchowo nieśmiałego" [Dz 280]. Pisarz zarzuca więc rodakom brak krytycyzmu, dyscypliny intelektualnej oraz myślowej aktywności i odwagi. Jednocześnie - projektując własne stanowisko poznawcze - deklaruje, 
że myśl „rodzi się jako obojętny surogat ślepych dążeń, potrzeb, namiętności” [Dz 211]. Nietrudno spostrzec, że w praktyce Gombrowicz stwierdza afektywne podłoże każdego aktu myślowego, swoiste myślenie przez czucie. Z tej perspektywy bardziej logiczna staje się argumentacja autora deklarującego, że „nie wierzy w filozofię nieerotyczną” i „nie ufa myśleniu, które wyzwala się z płci" [Dz 6o9], co może oznaczać, że filozofię i myślenie w ogóle uznaje za równie racjonalne, co cielesno-odczuciowe. Nie przypadkiem te uwagi pojawiają się w autointerpretacji Pornografii, która według autora ma być powieściową "próbą odnowienia polskiego erotyzmu”. Miało do tego dojść dzięki „ciału” młodych, przez które można „dotrzeć do pewnych antynomii ducha" [Dz 615].

Pomysł jest chyba bardziej perwersyjny, niż może zdawać się na pierwszy rzut oka, i rozpięty jest między trzema aktantami - cielesną parą młodych, (nie) obecnymi Żydami i rozdeptaną glistą. Obfitującej w spostrzeżenia wyprawie do Ostrowca odpowiada scena przyziemnej męki dżdżownicy. Nie chodzi jednak wyłącznie o metaforyczne korespondowanie napięć. Śmierć zadana przez młodych wspólnymi siłami staje się fundamentem konstytuowanej w powieści wspólnoty afektywnej. Działanie Karola i Heni stanowi pierwszy rzeczywisty przejaw ich współgrania z Fryderykiem i Witoldem, którzy - ożywieni i podbudowani wymową gestu - przekonują się o słuszności swoich perwersyjnych skojarzeń. Powstaje jednak pytanie, jakie może mieć to znaczenie w porządku pozatekstowym? Otóż wydaje się, że Gombrowicz marzy, by ten mikroincydent uczynić bardziej generalną metodą działania, by analogiczny mechanizm „ożywił” pogrążone w marazmie polskie społeczeństwo:

A jeśli Pornografia jest próbą odnowienia polskiego erotyzmu? Próbą odnalezienia erotyzmu, który by bardziej odpowiadał naszemu losowi - i naszej historii z lat ostatnich, złożonej z gwałtów, niewolnictwa, poniżenia, walk szczenięcych, będącej zstąpieniem w ciemną krańcowość świadomości i ciała? A może Pornografia to polski, nowoczesny, erotyczny, poemat narodowy? [Dz 615-616]

Nie chodzi chyba wyłącznie o erotykę, ale zgodnie z zasadą tak pomyślanej „filozofii erotycznej” o myślenie przez instynkty, popędy, afekty. Ale nie tylko. Pisarz wyraźnie wskazuje, że szuka recepty adekwatnej do „naszego losu z lat ostatnich". W Pornografii uwidacznia oddziaływanie zróżnicowanych ontologicznie bytów: anonimowych ofiar poległych na „polach zdziczałych wojną”, 
(nie)obecnych Żydów i kolejno mordowanych bohaterów: Amelii, Siemiana, Wacława i Skuziaka. Zatem charakter wspólnoty budowanej w świecie powieściowym sugeruje, że chodzi o włączenie w obręb refleksji także tych, których obecność nie jest wcale oczywista.

Gombrowicz konstatuje oscylujący na granicy bycia i nie-bycia, w gruncie rzeczy widmowy charakter społeczeństwa, i - paradoksalnie - uświadamia Polakom, że jedyną szansą na przebudzenie z tego letargu jest powrót do minionego, spotkanie z własnymi widmami i uznanie ich w porządku narracji. Gombrowicz zdaje się sugerować, że nie sposób dłużej wypierać mar, które - choć odtrącane - i tak są nieodmiennie obecne i pokutują w przestrzeni zbiorowej. O ile prawdą jest, że „historia jest zawsze naznaczona brakiem”"13, o tyle w diagnozie Gombrowicza historia okazuje się przepełniona i przeciążona różnymi formami obecności. Pornografia pomyślana jest jako celowy powrót do lat wojennych, by - niczym w projekcji w zwolnionym tempie móc przeżyć i odczuć to jeszcze raz, na nowo i świadomie. Zapewne nie bez przyczyny status niektórych postaci jest niejasny, rozchwiany, jak gdyby były one nie tylko sobą, lecz reprezentowały kogoś jeszcze innego - np. niemogąca wydobyć z siebie głosu kobieta o „dość subtelnej twarzy, w chustce, jaką noszą baby" w jedwabnej sukni wieczorowej spotkana na drodze do Ostrowca [P 68] czy sam Fryderyk, który "nic tylko zachowywał się" z „niestrudzoną nieprzyzwoitością milcząco-krzyczącą" i z „tym dialogiem prowadzonym uparcie... z... kim właściwie?...", z jego „wiedzą?, tą wiedzą jego o...?” [P 8].

Narracja stanowi zaproszenie do wspólnoty żywych i umarłych. Chodzi o autorefleksję, krytycyzm i dopuszczenie do siebie perspektywy, że wskutek zrządzeń losu, określonego położenia, sąsiedztwa, decyzji politycznych i działań militarnych, wskutek zapętleń historii, polskiej aktywności, a kiedy indziej inercji lub obojętności społeczeństwo nie wypracuje nowych struktur odczuwania, jeśli nie uzna swoich win i strat oraz nie pogodzi się z własnymi widmami. Z tej perspektywy Pornografia jawi się jako propozycja dostrzeżenia i zwerbalizowania tego, od czego przez lata się odwracano i co zwykle - jak słusznie zauważa Katarzyna Bojarska - prowadzi do „zerwania łączności z byciem i zaniedbania relacji ze światem"14.

K. Bojarska Żona Lota: patrzenie za siebie i możliwość widzenia historii, w: Kobiety i historia. Od niewidzialności do sprawczości, red. K. Bałżewska, D. Korczyńska-Partyka, A. Wódkowska, Wydawnictwo UG, Gdańsk 2015, s. 190.

14 Tamże, s. 191. 
Więcej - Gombrowicz w dość przebiegły sposób wystawia powojennego czytelnika na konieczność spoglądania "na swoje dawne niepatrzenie”. Strategia polega na „kuszeniu” odbiorcy pozorem łatwości i banalności powieściowej fabuły:

jakaż to bezczelność z mojej strony - uciekać się do tak porywająco-melodyjnych tematów! I to dziś, gdy [...] nowoczesny a szanujący się pisarz unika przynęt, jest trudny i woli odstręczać, niż kusić. A ja? Ja właśnie na odwrót, pakuję w tekst wszystkie smaczne smaki, wszystkie urocze uroki, faszeruję podnieceniami i krasami, nie chcę pisania suchego [...], aby dojść, jeśli się uda, do czegoś bardziej jeszcze „biorącego”... [Dz 607].

Jednocześnie we wstępie do Pornografii autor deklaruje, że „nawet może pomyślane to było, w pierwszym rzucie, odrobinę na wzór taniego romansu" [P 5]. Jerzy Jarzębski słusznie zauważa, że Gombrowicz operuje konwencjami popularnych gatunków, by skłonić odbiorcę do współpracy, "manipulować, wytwarzać w nim napięcie lub strach"15, a także „wciągać adresata utworu we współodpowiedzialność za perwersję powieściowej anegdoty"16. Jest to ważne ze względu na szanse powodzenia operacji prowadzonej „przez powieść" między Gombrowiczem a odbiorcą, gdyż „czysta świadomość musi być znowu zanurzona w ciele, w płci, w Erosie [...]. Świadomość dyktuje nam przeświadczenie, że jest ostateczna i niemożliwa byłaby jej praca bez tej pewności - ale rezultaty tego jej działania mogą być przywrócone życiu, ujęte z innej pozycji, przez innego ducha" [Dz 609].

Właśnie do tego „zanurzenia w ciele" potrzebna jest autorowi eskalacja (nie tylko) erotycznego napięcia między bohaterami - „żeby struna jak najbardziej była napięta i wibrująca" [WA 4729] - wibrująca na tyle, by pobudzić, skusić pozorem romansowej aury, a następnie „usidlić” czytelnika i uczynić podatnym na estetyczne i etyczne próby. Stawka jest wysoka i niejako „podwójna": sam Gombrowicz racjonalizuje swoje wybory i choć przekonuje, że brzydzi się melodramatem narodu, to jednak chce go „uleczyć" $\mathrm{i}$ uświadomić specyficznymi środkami. Jednocześnie perwersyjnie fantazjuje o podglądaniu Polski wojennej i tym samym powraca do własnego, zapewne bolesnego kompleksu „dezertera” i „uciekiniera”. I zdaje się, że to samo zaleca swojemu odbiorcy. Zaangażowanie go i uwikłanie ma służyć afektywnemu

15 J. Jarzębski Gra w Gombrowicza, PIW, Warszawa 1982, s. 360.

16 Tamże, s. 368. 
i myślowemu powrotowi powojennego czytelnika do lat wojennych oraz refleksji nad własną postawą. Nie jest chyba przypadkiem ciągłe dociekanie Gombrowicza winy lub niewinności bohaterów Pornografii. Podobnie znaczący jest sposób relacjonowania zachowan - zarówno mieszkańców „dziwnego” Ostrowca, jak i domowników dworu Hipolita, którzy - zasklepieni w swoim świecie, zabarykadowani i zamknięci - nie zważają w gruncie rzeczy na to, co działo się i dzieje na „polach zdziczałych wojną". Dominique de Roux dość enigmatycznie określił Gombrowicza mianem „antyświadka"17. Jest to nad wyraz celne: pisarz nie chciał czynnie uczestniczyć w wojnie, ale też nie wyobrażał sobie, by tylko biernie patrzeć na postępujący rozpad. Co ciekawe, pierwotnie tytułował powieść jako „Akteon”, co kojarzy się jednoznacznie z mitycznym podglądaczem, zresztą surowo ukaranym za swój czyn.

Gombrowicz dopiero po latach podejmuje się trudnej fantazji o roli „bystandera", a „podglądanie wstydliwe i niechętne, jakby z kąta” [P 49] czyni głównym motywem powieści. Niemniej, dokonując tego gestu, oczekuje analogicznego aktu odwagi polskiego społeczeństwa: przypomnienia sobie tego, od czego niegdyś odwracano wzrok ${ }^{\mathbf{1 8}}$, ocknięcia się z „prześnionej rewolucji" mieszkańców Ostrowca i wielu innych miast i wsi, którzy krzątali się nerwowo po wywiezieniu Żydów, wreszcie - odczucia na nowo ówczesnej obojętności, satysfakcji lub bezsilności.

W informacji otwierającej powieść pojawia się uwaga: „Pornografia dzieje się w Polsce lat wojennych. Dlaczego? [...] trochę na przekór - żeby podsunąć narodowi, iż w jego łonie zmieszczą się inne konflikty, dramaty, idee, oprócz tych... teoretycznie ustalonych". Właśnie tego podejmuje się Gombrowicz: pragnie przełamać dotychczasowe myślenie performatywno-życzeniowe i unieważnić zaklinanie rzeczywistości. Jednocześnie chce - napięciami, pobudzeniami, „wciągającą" erotyką - prowokować do otwarcia na inne wersje przeszłości, które - raz uświadomione - dopiero „zmieszczą się w łonie" czy w polu wyobrażenia. Istotne jest też pragnienie, by powieść była „statkiem korsarskim”, który „przemyca sporo dynamitu, aby rozsadzić nasze dotychczasowe uczucia narodowe" [TA 45]. Pisarz zdaje sobie też sprawę, że wskutek swoich „oddolnych" strategii działania nieopatrznie „stał się szkodnikiem” i że dopiero „pewna ewolucja odczuwania” [T 124] może

17

18

D. de Roux Gombrowicz - odprężenie i napięcia, s. 163.

Do czego - za twórcami teatralnymi - nakłania Grzegorz Niziołek w Polskim teatrze Zagłady، Instytut Teatralny im. Zbigniewa Raszewskiego, Wydawnictwo Krytyki Politycznej, Warszawa 2013. Dziękuję Grzegorzowi Niziołkowi za mobilizację do napisania tego artykułu. 
pozwolić na ukształtowanie nowoczesnego czytelnika, dla którego jego „literatura nie jest jedynie burzeniem” i który „dzięki niej nauczy się czerpać siły i stanowczość zdolną przetrzymać historyczne kataklizmy” [WA 4735]. Kłopot w tym, że „przewietrzenie” uczuć byłoby według Gombrowicza możliwe wyłącznie przez gościnność i otwarcie na mary przeszłości, a w dalszym planie „odnowienie polskiego erotyzmu” [V 420]. Z kolei by osiągnąć ten cel, konieczna jest praca pamięci i świadomości, schodzenie „w dół”, otwarcie na ten „erotyzm, który by bardziej odpowiadał naszemu losowi” [V 420]. Jednak pokłady „ciemnej krańcowości” zasłonięte są zwykle „całkiem współczesnymi truciznami, ostatnim «krzykiem bólu»..." [V 420]. I „to tak w kółko każdy zawsze" [I 31-32].

\section{Abstract}

\section{Agnieszka Dauksza}

JAGIELLONIAN UNIVERSITY (CRACOW)

The Burden of (Not) Being There: Gombrowicz's Position towards the War and Jews

In her careful new reading of Witold Gombrowicz's novel Pornografia Dauksza traces elements that indicate the essential role of passages concerning the war, its impact and consequences. Her affective analysis reveals Gombrowicz's singular obsession with the war, with the lack of agency and with (anti)testimony. A particularly important problem is the presence/absence of Jews in the novel's fictional reality. Dauksza explores Gombrowicz's relationships to Jews and points out how important that relationship is within his work. She also engages with his diagnoses and comments on postwar Polish society and with his remedies for the spectral status of that formation.

\section{Keywords}

Gombrowicz, war, Jews, spectres, Pornografia 